\title{
REPORT: SUMMARY OF THE WORKSHOP “ASPECTS OF HIGH-PRECISION RADIOCARBON CALIBRATION"
}

\author{
BERND KROMER, ${ }^{1}$ JANET AMBERS, ${ }^{2}$ M. G. L. BAILLIE, ${ }^{3}$ PAUL E. DAMON, ${ }^{4}$ \\ VAGO HESSHAIMER, ${ }^{1}$ JUTTA HOFMANN, ${ }^{5}$ OLAF JÖRIS, ${ }^{6}$ INGEBORG LEVIN, ${ }^{7}$ \\ S. W. MANNING ${ }^{8}$ F. G. MCCORMAC, ${ }^{3}$ JOHANNES VAN DER PLICHT, ${ }^{9}$ MARCO SPURK, ${ }^{5}$ \\ MINZE STUIVER ${ }^{10}$ and BERNHARD WENINGER ${ }^{11}$
}

From October 4 to 6,1996, a workshop addressing various aspects of high-precision radiocarbon calibration was held in the Wissenschaftsforum, Heidelberg, Germany. The participants are listed above. The discussion and conclusions of the workshop are summarized in the following sections.

\section{Corrections of the Hohenheim German Oak and Pine Chronology}

Recently, in an intercomparison of the Hohenheim German oak chronology (Becker 1993) and the Göttingen chronology (Leuschner and Delorme 1988), an error was discovered in the former (Leuschner, in preparation). Due to an error in adding sections at $5241 \mathrm{BC}, 41 \mathrm{yr}$ are missing in the published Hohenheim chronology. After correction of the error, the two chronologies synchronize over their entire common length, back to $7200 \mathrm{BC}$.

The correction leads to a 41-yr shift to older ages for all calibration data based on the Hohenheim German oak chronology prior to $5241 \mathrm{BC}$. This error explains 41 yr of the 54-yr discrepancy between the Seattle and Belfast data sets, as mentioned in Stuiver and Pearson (1993) and Pearson and Stuiver (1993), and in a footnote in the output of the program CALIB Version 3 (Stuiver and Reimer 1993). It was pointed out earlier that this discrepancy may have been caused by an error in the dendroscale (e.g., McCormac, Baillie and Pilcher 1995).

Before $7200 \mathrm{BC}$, the Hohenheim German oak is again externally replicated piece-wise by a floating section of the Göttingen chronology, back to $7800 \mathrm{BC}$. Due to the removal of suspect trees in the course of rebuilding the Hohenheim chronologies, an interval of low replication prior to $7800 \mathrm{BC}$ now exists. Therefore, the earliest oak section ( $c a .8050-7800 \mathrm{BC}$ ) is considered to be floating.

In addition, the tentative ring-width synchronization between German pine and German oak as given by Bernd Becker (Becker 1993; Kromer and Becker 1993) is no longer considered valid. At present, the German pine chronology must be regarded as floating. ${ }^{14} \mathrm{C}$-based evidence (wigglematching of oak and pine at $8800{ }^{14} \mathrm{C}$ BP and the slope of the long-term $\Delta{ }^{14} \mathrm{C}$ (Björck et al. 1996)), however, enables its approximate absolute placement. This leads to a likely estimated minimum shift by +120 dendroyears to older ages for the pine chronology when compared to the tentative treering synchronization of Becker (1993).

\footnotetext{
${ }^{1}$ Heidelberg Academy of Sciences, INF 366, D-69120 Heidelberg, Germany

2Department of Scientific Research, British Museum, London WC1B 3DG, England

${ }^{3}$ Palaeoecology Centre, The Queen's University, Belfast BT7 1NN, Northern Ireland

${ }^{4}$ Department of Geosciences, The University of Arizona, Tucson, Arizona 85721 USA

${ }^{5}$ Universität Hohenheim, D-70593 Stuttgart, Germany

${ }^{6}$ Museum Monrepos, Neuwied, Germany

'Institut für Umweltphysik, Universität Heidelberg, D-69120 Heidelberg, Germany

${ }^{8}$ Department of Archaeology, University of Reading, POB 218, Reading RG6 6AA, England

${ }^{9}$ Center for Isotope Research, Nijenborgh 4, NL-9747 AG Groningen, The Netherlands

${ }^{10}$ Quaternary Isotope Laboratory AJ-20, University of Washington, Seattle, Washington 98195 USA

${ }^{11}$ Institut für Ur-und Frühgeschichte, Weyertal 125, D-50923 Köln, Germany
} 


\section{2. ${ }^{14} \mathrm{C}$ Calibration Data Sets}

The Belfast laboratory presented evidence to support the original ${ }^{14} \mathrm{C}$ data set based on Irish oak (Pearson et al. 1986) and expressed concern about the shift of $c a .18 \mathrm{yr}$ toward older dates given in the revised 1993 Calibration Issue of Radiocarbon (Pearson, Becker and Qua 1993). They stated that ongoing measurements between Belfast and the University of Waikato Laboratories that repeat the 2nd millennium AD Irish oak, at decadal intervals, in both laboratories, will provide firm evidence for the absolute activity of the Irish oak and the validity of either the 1993 or 1986 data sets. The results of this exercise will be complete in ca. $2 \mathrm{yr}$ and will be published in Radiocarbon.

\section{Location-Dependent ${ }^{14} \mathrm{C}$ Differences (Northern Hemisphere)}

Damon, Chen and Linick (1989), Jirikowic and Kalin (1993) and McCormac, Baillie and Pilcher (1995) have suggested that differences may exist between the activities of wood from different locations. McCormac, Baillie and Pilcher (1995) showed measured differences between Irish oak, German oak and North American wood when contemporaneous samples of these woods were dated in the same laboratory. The issue was discussed during the workshop using all available published high-precision ${ }^{14} \mathrm{C}$ data sets and comparing data over their respective common intervals (see references cited above, plus Vogel et al. 1993; Vogel and van der Plicht 1993; Linick et al. 1986; Kalin et al. 1995; van der Plicht, Jansma and Kars 1995). Because of possible laboratory offsets it was agreed that only comparisons made in a single laboratory were valid for regional comparisons. The correction of the dates for the error in the German dendrochronology of $41 \mathrm{yr}$ improves the compatibility of the Belfast and Seattle measurements in the interval 5180-5500 BC. However, at the time of writing, the wood used in the German oak / Irish oak comparison (McCormac, Baillie and Pilcher 1995) does not seem to have been affected by the dendrochronological error, and thus an unexplained offset still exists between German and Irish oak of $39 \pm 8 \mathrm{yr}$ in the interval 4910-5170 BC. This requires further investigation.

Small systematic differences that exist over the length of the calibration chronologies may represent laboratory offsets. This statement does not rule out location-dependent ${ }^{14} \mathrm{C}$ anomalies in special situations, e.g., due to release of aged ${ }^{14} \mathrm{CO}_{2}$ from soils during thawing in arctic areas (Damon 1995) or phase differences on the scale of a few years (Jirikowic and Kalin 1993); these conditions, however, do not apply to the decadal or bidecadal tree-ring series used for ${ }^{14} \mathrm{C}$ calibration.

The relation between European and North American wood has been studied using Douglas-fir and bristlecone pine (BCP) for the American side, and the European oak series for Europe. Douglas-fir does not show a measurable difference ( $>15 \mathrm{yr}$ ) from German and Irish oak for the substantial data set that was established for the time interval AD 900-1840 (Pearson et al. 1986; Kalin et al. 1995; Stuiver and Becker 1993; van der Plicht and McCormac 1995). The same conclusion is drawn from the comparison of BCP with German oak at $2000 \mathrm{BC}$ (Vogel et al. 1993). In the comparison at 500 BC (McCormac, Baillie and Pilcher 1995), Irish oak appears systematically younger by $c a .40 \mathrm{yr}$, and in the 7th millennium $\mathrm{BC},{ }^{14} \mathrm{C}$ offsets between German oak (corrected dendroscale) and $\mathrm{BCP}$ (Linick et al. 1986) are even larger during intervals of up to a century.

Presently the causes of these discrepancies cannot be resolved; it was noted, however, that they are largest for older intervals, and for large differences in the years when the ${ }^{14} \mathrm{C}$ analyses were made in the respective laboratories. In addition, errors in wood selection and/or ring-width synchronization have been noted in the course of the cooperation between dendrochronology and ${ }^{14} \mathrm{C}$ dating. Therefore, the workshop participants agreed on further intercomparison of BCP to the European oak series at selected intervals to help resolve this open issue. 
Further support for only minimal intrahemispheric gradients was offered from the presentation of the modern atmospheric ${ }^{14} \mathrm{CO}_{2}$ network (Levin et al. 1992). When the present-day fossil-fuel ${ }^{14} \mathrm{CO}_{2}$ depression of the mid-Northern Hemisphere is scaled to the ${ }^{14} \mathrm{C}$-depleted North Pacific source of $\mathrm{CO}_{2}$, an atmospheric signal of $0.5-1 \%$ is estimated for the preindustrial situation. This estimate is identical to the GC-model results of Braziunas, Fung and Stuiver (1995), which show strong zonal homogeneity in the Northern Hemisphere, with maximum gradient of $+1 \% 0$ in mid-latitudes, from which all tree-ring chronologies used for ${ }^{14} \mathrm{C}$ calibration derive.

\section{Error Estimates During Wiggle-Matching}

Some calibration programs offer the option of wiggle-matching of floating ${ }^{14} \mathrm{C}$ series, usually from tree rings, to the calibration data set, taking into account only the quoted (Poisson) error of the individual ${ }^{14} \mathrm{C}$ dates. This procedure leads to unrealistically precise ranges of the fitted age (e.g., below one decade), since a variety of other error factors of larger magnitude are not allowed for. Realistic error calculation must include allowance for appropriate interlaboratory offsets, the mismatch of the fitted series to the (bi-)decadal spacing of the calibration set and location-dependent anomalies in ${ }^{14} \mathrm{C}$ activity. Each of these errors is in the order of $\pm 10-15 \mathrm{yr}$ under optimal conditions; hence realistic errors on wiggle-matches should be on the order of $20-30{ }^{14} \mathrm{C}$ yr at a minimum. This error must then further be translated into calendar years according to the shape of the calibration curve.

It is therefore recommended that in future releases of these programs, user-alterable defaults for additional error components be implemented.

\section{Future Revisions of the Calibration Data Sets}

The corrections mentioned above entail small revisions of the published ${ }^{14} \mathrm{C}$ calibration data sets, over three separate intervals:

- For the period AD 1950 to $5500 \mathrm{BC}$, a return to the Belfast 1986 data would result in an average shift of $9 \mathrm{yr}$ to younger ages as compared to the INTCAL93 data set (Stuiver and Reimer 1993). This correction is small with respect to the uncertainty of even high-precision ${ }^{14} \mathrm{C}$ dates and should not concern most users.

- The interval 5500-7800 BC needs to be corrected for the 41-yr shift of the Hohenheim German oak, which is the only source of European wood for ${ }^{14} \mathrm{C}$ calibration in this interval. The (dendroscale-corrected) published results (Pearson, Becker and Qua 1993; Stuiver and Becker 1993) will be complemented by additional German oak measurements performed in Seattle and Heidelberg since 1993.

- For the earliest Holocene interval, back to $c a .11,600 \mathrm{cal}$ BP, only approximate calibrated ages can be obtained from the floating German oak and pine sections, as outlined above.

These changes will be incorporated into revised calibration data sets; we envisage making them available on the Internet at the time of the 16th International Radiocarbon Conference in Groningen.

\section{Concluding Remarks}

The issues discussed at the workshop reflect advances in high-precision ${ }^{14} \mathrm{C}$ measurement techniques, which are the basis for state-of-the-art ${ }^{14} \mathrm{C}$ applications in geophysics and carbon cycle studies, e.g., of solar modulation of ${ }^{14} \mathrm{C}$ production or of isotopic signatures in atmospheric $\mathrm{CO}_{2}$ as indicators of the contribution of the various carbon reservoirs to the carbon cycle.

For calibrating of Neolithic and younger archaeological samples, the revisions to the published data set appear of very minor importance. For the older intervals, the changes introduced by the modifi- 
cations of the tree-ring scale result in a closer agreement of ${ }^{14} \mathrm{C}$-calibrated archives with other time scales, e.g., from ice cores or varved sediments, at the end of the Late Glacial (Björck et al. 1996).

\section{REFERENCES}

Becker, B. 1993 An 11,000-year German oak and pine dendrochronology for radiocarbon calibration. In Stuiver, M., Long, A. and Kra, R. S., eds., Calibration 1993. Radiocarbon 35(1): 201-213.

Björck, S., Kromer, B., Johnsen, S., Bennicke, O., Hammarlund, D., Lemdahl, G., Possnert, G., Rasmussen, T. L., Wohlfahrt, B., Hammer, C. U. and Spurk, M. 1996 Synchronized terrestrial-atmospheric deglacial records around the North Atlantic. Science 274: 11551159.

Braziunas, T. F., Fung, I. Y. and Stuiver, M. 1995 The preindustrial atmospheric ${ }^{14} \mathrm{CO}_{2}$ latitudinal gradient as related to exchanges among atmospheric, oceanic, and terrestrial reservoirs. Global Biogeochemical Cycles 9(4): 565-584.

Damon, P. E. 1995 Note concerning "Intercomparison of high-precision ${ }^{14} \mathrm{C}$ measurements at the University of Arizona and The Queen's University of Belfast Radiocarbon Laboratories" by Kalin et al. (1995) and the regional effect. Radiocarbon 37(3): 955-959.

Damon, P., Cheng, S. and Linick, T. W. 1989 Fine and hyperfine structure in the spectrum of secular variations of atmospheric ${ }^{14} \mathrm{C}$. In Long, A., Kra, R. S. and SrdoË, D., eds, Proceedings of the 13 th International ${ }^{14} \mathrm{C}$ Conference. Radiocarbon 31(3): 704-718.

Jirikowic, J. L. and Kalin, R. M. 1993 A possible paleoclimatic ENSO indicator in the spatial variation of annual tree-ring ${ }^{14} \mathrm{C}$. Geophysical Research Letters 20 (6): 439-442.

Kalin, R. M., McCormac, F. G., Damon, P. E., Eastoe, C. J. and Long, A. 1995 Intercomparison of high-precision ${ }^{14} \mathrm{C}$ measurements at the University of Arizona and The Queen's University of Belfast radiocarbon laboratories. Radiocarbon 37(1): 33-38.

Kromer, B. and Becker, B. 1993 German oak and pine ${ }^{14} \mathrm{C}$ calibration, 7200-9439 BC. In Stuiver, M., Long, A. and $\mathrm{Kra}$, R. S., eds., Calibration 1993. Radiocarbon 35(1): 125-135.

Leuschner, H. H. (ms.) Comparison and revision of the ultra-long German oak tree-ring chronologies. In preparation.

Leuschner, H. H. and Delorme, A. 1988 Tree-ring work in Göttingen. In Hackens, T., Munaut, A. V. and Till, C., eds., Wood and Archaeology: Acts of the European Symposium held at Louvain-la-Neuve, October 1987. PACT 22. Strasbourg, Conseil de l'Europe: 123-132.

Levin, I., Bösinger, R., Bonani, G., Francey, R. J., Kromer, B., Münnich, K. O., Suter, M., Trivett, N. B. A. and Wölfli, W. 1992 Radiocarbon in atmospheric carbon dioxide and methane: Global distribution and trends. In Taylor, R. E., Long, A. and Kra, R. S., eds., Radiocarbon after Four Decades: An Interdisciplinary Perspective. New York, Springer-Verlag: 503-518.
Linick, T. W., Long, A., Damon, P. E. and Ferguson, C. W. 1986 High-precision radiocarbon dating of bristlecone pine from 6554 to 5350 BC. In Stuiver, M. and $\mathrm{Kra}, \mathrm{R}$., eds., Proceedings of the 12 th International ${ }^{14} \mathrm{C}$ Conference. Radiocarbon 28(2B): 943-953.

McCormac, F. G., Baillie, M. G. L. and Pilcher, J. R. 1995 Location-dependent differences in the ${ }^{14} \mathrm{C}$ content of wood. In Cook, G. T., Harkness, D. D., Miller, B. F. and Scott, E. M., eds., Proceedings of the 15th International ${ }^{14} \mathrm{C}$ Conference. Radiocarbon 37(2): 395407.

Pearson, G. W., Becker, B. and Qua, F. 1993 High-precision ${ }^{14} \mathrm{C}$ measurements of German and Irish oaks to show the natural $14 \mathrm{C}$ variations from 7890 to 5000 BC. In Stuiver, M., Long, A. and Kra, R. S., eds., Calibration 1993. Radiocarbon 35(1): 93-104.

Pearson, G. W., Pilcher, J. R., Baillie, M. G. L., Corbett, D. M. and Qua, F. $1986 \mathrm{High}$-precision ${ }^{14} \mathrm{C}$ measurements of Irish oaks to show the natural ${ }^{14} \mathrm{C}$ variations from AD 1840 to 5210 BC. In Stuiver, M. and Kra, R., eds., Proceedings of the 12 th International ${ }^{14} \mathrm{C}$ Conference. Radiocarbon 28(2B): 911-934.

Pearson, G. W. and Stuiver, M. 1993 High-precision bidecadal calibration of the radiocarbon time scale, 500-2500 BC. In Stuiver, M., Long, A. and Kra, R. S., eds., Calibration 1993. Radiocarbon 35(1): 25-33.

Stuiver, M. and Becker, B. 1993 High-precision decadal calibration of the radiocarbon time scale, AD 19506000 BC. In Stuiver, M., Long, A. and Kra, R. S., eds., Calibration 1993. Radiocarbon 35(1): 35-65.

Stuiver, M. and Pearson, G. W. 1993 High-precision bidecadal calibration of the radiocarbon time scale, $A D$ 1950-500 BC and 2500-6000 BC. In Stuiver, M., Long, A. and Kra, R. S., eds., Calibration 1993. Radiocarbon 35(1): 1-23.

Stuiver, M. and Reimer, P. J. 1993 Extended ${ }^{14} \mathrm{C}$ data base and revised CALIB 3.0 ${ }^{14} \mathrm{C}$ age calibration program. In Stuiver, M., Long, A. and Kra, R. S., eds., Calibration 1993. Radiocarbon 35(1): 215-230.

van der Plicht, J., Jansma, E. and Kars, H. 1995 The "Amsterdam Castle": A case study of wiggle matching and the proper calibration curve. Radiocarbon 37(3): 965-968.

van der Plicht, J. and McCormac, F. G. 1995 A Note on calibration curves. Radiocarbon 37(3): 969-970.

Vogel, J. C., Fuls, A., Visser, E. and Becker, B. 1993 Pretoria calibration curve for short-lived samples, 1930 3350 BC. In Stuiver, M., Long, A. and Kra, R. S., eds., Calibration 1993. Radiocarbon 35(1): 73-85.

Vogel, J. C. and van der Plicht, J. 1993 Calibration curve for short-lived samples, 1900-3900 BC. In Stuiver, M., Long, A. and Kra, R. S., eds., Calibration 1993. Radiocarbon 35(1): 87-91. 